\title{
Integrating Immigrants through the Policy of Multiculturalism as a State's New Response to the Sovereignty Challenge
}

\author{
Anna Vorobyova
}

Inclusion may be of more relevance to the stability of the system than to the interests of the included.

Philip Cerny

\begin{abstract}
Today the EU and Canada experience a significant international migration inflow that requires a delicate treatment on the government side which would not contradict with these countries' adherence to a liberal nation-state idea.

The non-ratification of the EU Constitution precluded the creation of a common immigration policy that could facilitate and level the social integration of immigrants within the EU member states that currently have different historically shaped strategies towards the newcomers. Even though the legal and economic barriers for immigration and naturalization have been reasonably decreased over the past decades across the EU, the legacies of nationalizing citizenship laws are still persistent and immigrants are expected to integrate into the host cultures. These path dependent repercussions contradict the idea of a liberal nation-state and erect the second level barriers (besides legal and economic ones) for integration of immigrants into the host societies. These cultural barriers are more persistent in the social consciousness than the institutionalized ones, which is a reason for why liberalizing laws are not the most effective means for facilitating the immigrants' integration into the host societies. This situation of intensive immigration combined with the low opportunities for social integration gives grounds to instability and dissatisfaction within certain social groups in the EU.

This paper investigates how multiculturalism policy in Canada contributes to a higher level of immigrants' integration into Canadian society as compared to the EU memberstates. Moreover, the novel information from the Centre of Excellence for the Study of Immigration at Simon Fraser University suggests that maintenance of immigrant ethnicities contributes to the overall economic success of a country, which is another reason for the introducing multiculturalism and a common EU immigration policy.
\end{abstract}




\section{Introduction}

The idea introduced with the essay title seems quite counterintuitive to the predominant scholarly view on the Canadian policy of multiculturalism which is often suggested as a solution to the "ethnic dilemmas" in the EU countries (Carens, et al. 1994, Inglis, 2003, Kymlicka, 1998, Castles, 1992, et al. 1994). The paper aims at reassessing this accepted idea since the suggestions of adapting multiculturalism across European countries become more salient in the light of the enlarged nature of the EU, new immigration law in France, ethno-cultural tensions in Denmark, Estonia and Latvia.

\section{Literature Debate and Research Question Background}

The debate about nation-state sovereignty is an ongoing one and is shaped around opposing views on whether cultural, trade, value, business, and political globalizations irreversibly encroach on or mildly transformed nation-state sovereignty. The academic areas that deal with this issue are numerous, ranging from art history to international political economy, from identity politics and development studies to the international law regimes. One of the obvious results of globalization is an increased legal and illegal migration of people across state borders that challenge a recognized phrase coined by John Torpey that "modern states expropriated from individuals and private entities the legitimate means of movement”. ${ }^{1}$

\footnotetext{
${ }^{1}$ Torpey John, Coming and Going: On the State Monopolization of the Legitimate "Means of Movement", Sociological Theory, Vol. 16, No. 3. (November, 1998), p. 239.
} 
In the field of migration control there are two opposite strands of thought concerning the changing nature of state sovereignty. ${ }^{2}$ Some scholars (Jacobson, 1996, Sassen, 1996, 1998, Soysal, 1998) argue that the state’s capacity to control migration has been significantly diminished by neo-liberal international economy coupled with international human rights regime. Engbersen (2001) suggests that the state's capacity to control the entering flow of migration has not significantly changed; however, the state's efficiency in preventing illegal residency internally is dramatically challenged by ethnic communities and various strategies that immigrants employ quite successfully finding the loopholes in the law. Other scholars (Freeman, 1995, Joppke, 1998, Lahav and Guiraudon, 2000) disagree with the conclusion that state sovereignty is decreasing. Freeman (1995), Money (1997) and Joppke (1998) suggest that states are internally, rather than externally, limited in their ability to control immigration because of the institutional constraints of interest groups politics and political parties electoral pragmatism. Guiraudon and Lahav (2000) highlighted how states have managed to delegate migration policies to various international and domestic non-state actors, but that does not necessarily mean states are losing sovereignty or regressing in their ability to control migration. Thinking in terms of infrastructural state capacities defined by Michael Mann (1984) as an ability to hold the exclusive control over the territory at the expense of any other entity of non-territorial nature (such as church, business corporations, university) it might appear problematic to resolve the debate about migration control and state sovereignty. Even though delegating its authority to control migration over to the non-state entities might mean an extraterritoriality which is beyond the modern

\footnotetext{
${ }^{2}$ From now on, discussion of state sovereignty is limited to the Western developed nations that experience significant migration inflow.
} 
conventional understanding of a state, in my opinion, the very fact of delegating some authority initiated by the state itself signifies still the ultimate sovereignty of a state over its new partners in migration control. Assuming that the question of a state retaining major control of migration inflow might not be the only decisive indicator of its preserved sovereignty, I look at another vital aspect of state operation, namely, a state's historical pursuit of homogenizing a nation (Brubaker, 1992, Schulze, 1994).

Considering that the literature on migration control cannot resolve the debate about possible transformations in state sovereignty when exposed to significant movements of people, I shift attention from the policies controlling migration to the policies treating migration that has already occurred. As it is questionable if a state has ever held a complete control over its territory (Joppke, 1998), the increased level of migration nevertheless poses a problem for a state in terms of how to extend and maintain its sovereignty over the newcomers with the backgrounds more diverse than ever in all respects: geography, ethnicity, education, gender, income and others. The overwhelming diversity of newcomers poses a challenge to the state's sovereignty as the necessity of controlling the population under the state rule was often connected with the homogeneity and loyalty of the people (Brubaker, 1992, Schulze, 1994), which becomes quite complicated to ensure given the scope of the migrants' diversities. Thus the research question I intend to answer is what influences policies towards immigrants in a liberal democratic state today given both the increased diversity of the newcomers and the state's pursuit of internal stability through homogenizing its inhabitants? Apparently, today it is impossible to speak about “a state" as a unitary actor due to the democratization of the state apparatus and of its interaction with the society. Policies 
concerned with the immigrants are in particular influenced by various state actors with opposite interests. Bureaucracy is supposed to be persistently stricter about migration control both internally and at the state borders (Ellermann, 2005), whereas political parties and governments tend to change their positions according to election cycles and public attitudes (Freeman, 1995, Joppke, 1998, Money, 1997).

However, considering a significant part of literature which argues that state policies concerned with immigrants proceed almost exclusively at the elite level (Freeman, 1995, Giuraudon, 2000, Favell, 2001) for the narrow purpose of this research certain generalizations in the phenomenon of state seem to be justified. I suggest thinking of a state as a self-perpetuating open system with an interest in preserving its internal stability. The understanding of a state for this paper is framed in the conventional Weberian terms, but at a higher level of abstraction that is omitting various institutions and actors engaged in the process of immigrants' integration policy-making. A state will be considered as a territorial political organization that is endowed with exclusive sovereignty from the inhabitants of its territory and supported by its possession of the legitimate means of violence. State sovereignty is manifested in its authority to make collectively binding decisions and to be the last resort of responding to the citizens' claims. A state will be viewed as a coercive system interested and engaged in maintaining its internal stability through mitigating differences and cleavages within the population under its rule.

In addition to the challenge of increased diversity, the exercise of state sovereignty through homogenizing the inhabitants and ensuring their loyalty is furthermore contentious today given the liberal democratic discourse of protecting human 
rights, privacy, and ethnic minorities in addition to minimal emphasis on community. Indeed, as Freeman (1995) and Joppke (1998) suggest, principles of liberal democratic state functioning (pluralism, openness) is one of the major factors that forces the developed industrialized states to accept immigrants regardless of the unfavorable public opinion and despite the need to keep control over who resides on the state's territory. I extend this idea and would argue that: despite the increased diversity of the immigrants and the liberal democratic discourse a state still succeeds in maintaining its sovereignty through the same means of homogenizing the new residents and as a result a state still exists as a stable political-territorial organization with a population which is conformed into a nation according to some underlying shared values. Even though the process of policy-making in the area of the immigrants' treatment is not designed and executed unilaterally, its general direction and results seem to reveal the grand rationale behind it. I argue that the latter can be defined as the state's continuous pursuit of maintaining control over the population under its rule that historically took various forms and employed many strategies and which today can be defined as the politics of integrating immigrants.

\section{State Pursuit of Controlling its People}

As far as this research is concerned, the idea of authority in the early modern Europe faced three major changes that drastically diverged from the authority in the previous period conventionally called feudalism. These innovations were territorial demarcation, centralization and extra-personal nature of the office. Therefore, the 
Review of European and Russian Affairs vol. 2 issue 3/2006 @ RERA 2006 all rights reserved

ascension of a modern state required from the rulers to find new sources of legitimacy for this impersonal and remote apparatus claiming its right for coercion and exemption of resources (Tilly, 1990, Schulze, 1994). Search for a new linkage between a state and the inhabitants of the land claimed to be under the state's rule led to the various strategies such as: registering people and their property, standardization of measurements (Scott, 1998), coercive religious conversion (Schulze, 1994), nationwide printed media, unified symbols and holidays (Anderson, 1991), national education, official language and historiography (Gellner, 1983) and even mass conscription and warfare (Tilly, 1990). All these enterprises were initiated by the rulers at first to advance integration of the land inhabitants to a higher level such as shared membership in a political community; and afterwards to create a special and almost affectionate bond between a state and its population that can be named patriotism, nationalism, national identity, or the civic code of loyalty to the state. These affiliations were finally established in the concept of citizenship that encompasses not only mutually recognized rights and responsibilities between a state and an individual but more importantly points to the belonging of a citizen to a particular nation (Brubaker, 1992, Faist et al. 2004), to the political community with a distinct collective identity. This was possible since the idea of citizenship was originated as national citizenship, meaning that individuals related to the state in a very close and symbolic way, what some scholars even called "a genuine link" (Rittstieg, 1990: 1402, qtd in Faist, et. al. 2004). For this reason there is a debate about dual citizenship and an emerging post-national or even global citizenship since it is problematic to maintain "a genuine link" with two polities least to say with the humanity at large. The problem disappears if there is no place for this special genuine connection in 
the idea of citizenship but it is not how it emerged. Interestingly enough, the Soviet tradition of citizenship is quite different from the Western one exactly in the criteria of belonging. Soviet citizenship used to describe only formal legal relations between a state and an individual and it was clearly differentiated from the idea of patriotic adherence to the Soviet ideals of Communism that were supported by the ideology of class solidarity and not by the ties of nationality. The latter was fundamentally neglected in the USSR and reduced to the nominal label in the passport (Nahorna, 2002). Being a Soviet citizen meant adherence to the "higher" ideals of working class solidarity that crossed any national borders and denied any national differences. It is obvious from the collapse of the USSR, one of the reasons for which was nationalism, that citizenship without national belonging looses its power of integrating and affectionately affiliating individuals with a state.

Decreasing any kind of cleavages within the society was another vital interest of the state as they are sources of instability, anti-state protest claims and even separatism of some groups. Therefore, besides the initiatives noted above there was another set of state activities tailored at embracing and demarcating its inhabitants, which comprises modern citizenship (Brubaker, 1992). This legal connection of an individual with a polity was developed through balancing rights and duties of the citizens in relation to the state. The evolution of the modern citizenship regimes depicted by T.H. Marshall can be also understood as various contracts between the state and its citizens influenced by the circumstances which at times endangered state-society relations of loyalty and stability. Under this logic, welfare state was created to mitigate class divisions, which were dangerous to the extent of splitting one nation into two as Disraeli famously expressed it. 
State enfranchising responses to the labor and feminist movements, satisfying responses to the civil rights, handicapped, and sex minorities' movements all can be viewed as state pursuit of internal stability and self-preservation. If the inclusion of women and labor into political and social welfare community did not change but simply expanded the same universal citizenship to the new segments of population, the inclusion of various other minority groups qualitatively changed nature of citizenship. The innovation in the citizens' rights was in a differentiated treatment of the people by a state based on their belonging to a particular group within a larger society led to the idea of multicultural citizenship (Castles, 1994) that is widely considered as just, humanistic and democratic in political philosophy (Young, 1989, 1990, Taylor, 1994, Castles, 1992, 1994).

A totally different story may be told about state treatment of those distinct groups of population whose differences were along the lines of ethnicity, culture, religion or language. This inclusion was coercive and assimilatory in nature, especially in the first modern territorial states to emerge, such as France and Spain. Ethnic subgroups were either wiped out or fought against or negotiated to conform to the central source of authority and uniform language, religion and various other cultural practices. Later in the history those ethnic groups (the Basques, the Bretons, the Irish, the Scottish, the Walloons, the Flemish) who managed to preserve their identity different from the national one reiterated their claims on rights for a cultural distinctiveness to the central state. These claims were addressed through federalization, special public programs of preserving ethnic cultures, languages and through other forms of cultural autonomy. Again, these state policies seem liberal and humanistic in a way, however, state's concern with ethnic unrest, terrorism and separatism is driving those policies. Therefore, it is 
possible to argue that after initial coercive assimilation of the ethnicities into the mainstream nationwide culture, the state now chose a more sophisticated way of maintaining national homogeneity, namely, through preemption for the ethnic sentiments to take over the loyalty to a nation-state but at the same time allowing for certain freedom of expression of ethnic identity.

Again, all these inclusive activities of a state were largely motivated by its pursuit of internal stability and of a more homogeneous nation. It is worth emphasizing that the ethnic groups noted above were originally a population of a particular state and their demand of inclusion was based on their citizenship rights as of inhabitants' of this state. Conversely, immigrants face a different challenge in their interaction with a host state, on one hand, they want to preserve their identity but on the other, they have to accept the rules of the society they chose to enter. From the state perspective, immigrants are both dangerous as they bring new diversity, inequality and thus instability but on the other hand, their economies need immigrants and even human rights issues request accepting immigrants sometimes. This state-immigrant dilemma is well-described by Adrian Favell as immigrants being the last challenge of inclusion for the liberal democracies (Favell, 2001). As he demonstrated in his book and as this research supported his idea, liberal democracies found their escape in certain policies of integrating immigrants, namely, fair socioeconomic treatment to reduce social cleavages under condition of immigrants' conforming to the national culture. Various states succeeded differently in these policies accordingly to the extent of assimilation claims they pose on immigrants. The Canadian policy of multiculturalism in this respect appears to be one of the most successful as it faces the least amount of social cleavages between immigrants and nationals. 


\section{Analytical Framework}

What are the means that a state employs today in order to mitigate the differences and to keep control over the newcomers? What are the state policies towards its new residents that can shed light on the research question? There are several classifications of these policies possible, for instance, according to the legal status of migrants or to the rights and duties extended to them (denizens, naturalized citizens, first-, secondgeneration immigrants, illegal immigrants, migrant workers). However, my argument requires the policies that are concerned more with values and identity issues than with socioeconomic relations between a state and its new residents. In order to investigate whether a state still pursues nation homogeneity it seems more logical to explore the policies that reveal how a particular nation is imagined and whether or not the immigrants are expected to conform to this image. This policy would be an extrapolation of the particular citizenship regime onto the newcomers either through the process of naturalization and of the consequential integration of the immigrants into the traditionally imagined community of citizens. In this I follow Roger Brubaker's argument that cultural idioms historically shaped the citizenship regime of a particular nation around the core values that members of this nation adhere to.

I find also that Adrian Favell (1998, 2001) logically extends this argument onto how particular citizenship regimes shape the state policies of integrating immigrants according to these cultural idioms, so to say in order to become a member of a particular nation immigrants are expected to comply with the conventions and values embodied in the cultural idioms. Germany, Great Britain, France and the US are widely discussed in the literature as classical examples of the nations with particularly vivid cultural idioms 
of their citizenship and consequently shaped policies of integrating immigrants. Even though other European nations are not as discussed in the literature regarding their particular citizenship idioms, Brubaker's and Favell’s arguments seem quite applicable to any other nation-state, especially to the so called "old" historical nations. The challenges that arise in the European states due to their expectation of immigrants to integrate into the established cultural idiom are manifold: first, contradiction to the idea of liberal democracy professed by the EU members; second, aggravation of inconsistencies in the policies towards immigrants across the $\mathrm{EU}^{3}$ and lastly, creating serious internal tensions between the indigenous and immigrated citizens in many EU countries. One of the most widely proposed cures for these cleavages in Europe is a policy of multiculturalism as practiced in Canada (Carens, et al. 1994, Inglis, 2003) or Australia (Castles, 1992, et al. 1994). Canadian application of multiculturalism is renowned for the metaphor of “mosaic" as juxtaposed to the US "melting pot” and is discussed particularly positively by Will Kymlicka and Charles Taylor, which importantly means the acceptance of multiculturalism by both liberal and communitarian perspectives on citizenship and ethnic identities. It is suggested that multiculturalism values diversity, allows for preserving and expressing one's identity without major restrictions as long as it does not contradict with the liberal freedoms of others.

Before conducting this research I stood on the same position of assigning a high value to the idea of multiculturalism as the policy which aims at preserving and

\footnotetext{
${ }^{3}$ It is interesting to note that the non-ratification of the EU Constitution, which proposed a creation of a common immigration policy for the EU members, reinforces the assumption that states aim at preserving their sovereignty through homogenizing their populations and, therefore, try to retain their historically shaped cultural idioms of citizenship and of integrating the newcomers. There is also some evidence that common immigration policy was one of the reasons for the French and the Dutch to vote against the Constitution.
} 
Review of European and Russian Affairs vol. 2 issue 3/2006 @ RERA 2006 all rights reserved

developing particular ethnic and cultural identities. After completing the inquiry, I have some evidence to argue conversely that the policy of multiculturalism can be viewed as the newest accommodation necessitated by the liberal democratic discourse which essentially remains the same policy of conforming immigrants to the mainstream host culture. In this way, liberal democratic state still is able to exercise its sovereignty over the population through homogenizing ethnic and cultural differences within the policy of multiculturalism. Therefore, retrospectively my hypothesis was: it is likely to observe that a liberal democratic state has preserved its pursuit of nation homogeneity in order to ensure internal stability and loyalty of its citizens through the investigation of the policy of multiculturalism in Canada.

As a theoretical method to uncover this veiled state interest I chose discourse analysis of the language used in the official public documents discussing the principles and functioning of the multiculturalism policy in Canada. The prominent work that first introduced this method in studying the policies of integrating immigrants was Adrian Favell's book Philosophies of Integration: Immigration and the Idea of Citizenship in France and Britain (1998, 2001). He argued that an insightful research of immigration and integration policies, especially in France and Britain, can only be interpretative and consequently, studying merely formal laws and institutions is not adequate. Favell insisted that "Politics takes place within language: within rhetoric and argument, which divide up, categorize and bound the social and cultural context of the policies” (Favell, 2001:9). I agree with his idea that policy language is not just a reflection or a separate element of the debate on immigrants' integration but rather is a cognitive justification further constructing the policy in the path-dependent mode. Another significant example 
Review of European and Russian Affairs vol. 2 issue 3/2006 @ RERA 2006 all rights reserved

of employing discourse analysis in studying treatment of the migrants is a working paper by Peter S. Li Deconstructing Canada's Discourse of Immigrant Integration further developed as one of the approaches in his recent book Destination Canada: Immigration Debates and Issues (2003). Peter S. Li looked at how immigration critics, policymakers and political theorists view the concept of immigrants' integration from different perspectives of diversity in mind but at the same time converging on the idea that integration implies immigrants' conforming to the mainstream culture. He looked at the context in which those three discourses used concepts of integration and diversity and concluded two things of major relevance for this research: 1) rather than questioning the relationships between diversity and integration, advocates of multiculturalism accept the already existing Canadian culture as a standard of normalcy; 2) evaluation of immigrants' integration into Canadian society is based on how well their various ethnic, religious, and cultural practices are conformed to the mainstream Canadian culture. I will rely on his findings in the process of my deconstruction of the language used in the public policy reports on multiculturalism in Canada.

Another study on the Canadian multiculturalism policy only episodically employed discourse analysis in a book Selling Diversity by Yasmeen Abu-Laban and Christina Gabriel (2002). Their main focus was historical and institutional changes in this policy as influenced by internal political (government ideology) and external (globalization of business) factors, however, they also noted how the language of the politicians and business corporations reveals and supports the conclusions based on their observations of the empirical developments in the multiculturalism policy. In short, there was a significant shift in the official discourse about multiculturalism from the era of neo- 
conservative Mulroney government (up to 1993) that discussed multiculturalism as a profitable neo-liberal business card. Canadian corporations "sell” diversity around the globe, which basically means that successful sales depend largely on personal attachments of "hyphenated" Canadians with their home countries or with the business people of similar ethnic origin. This position on multiculturalism obviously did not require any public spending. Under a liberal PM Jean Chrétien the discourse on multiculturalism has changed to focusing on ethnic identities per se and their contribution to the Canadian national unity and cohesion. The major lens of the liberal multiculturalism policy became equality of opportunity, consistent with the reform liberal ideology, however, not necessarily with the amount of public spending on ensuring this equality. The liberal discourse of multiculturalism policy became a part of an overarching theme of protecting various minorities (gender, racial, sexual, ethnic) from discrimination. Overall, the book Selling Diversity again supports my choice of discourse analysis as an insightful method of inquiry in the field of state policies on integrating immigrants.

Besides the fact that there are some studies which successfully employed discourse analysis to my research focus earlier, another reason for me to choose this particular method of studying the policy of multiculturalism, is that phenomena involved here, namely, identity and ethnicity, are symbolic and require an interpretative rather than an institutional or policy approach. For instance, K. Fierlbeck (1996) pointed out that cultural identity is ambivalent in terms of public-private dichotomy as it is not clear whether state institutions or individuals should be ultimately responsible for the expression and preservation of the cultural identities. Another ambivalence is in how to 
balance liberal and communitarian values in the matters of identity, whether it should be regarded as a group phenomenon and a collective right or conversely as a right of an individual. Ethnicity and identity are one of the most irrational and symbolic phenomena that social sciences aspire to deal with because there is a strong sense of personal belonging and attachment hidden in those which does not require a logical or rational substantiation (Castoriadis, 1975, Smith, 1991). Almost always identity cannot or should not even be explained or justified for it expresses the necessity of a human being to belong to some group among which an ethnic group provides one of the most emotionally strong and irrational collective identities (Smith, 1991, Taylor, 1996).

Deconstructing the language of the official documents on the Canadian policy of multiculturalism, I am interested in the words that are relevant to my hypothesis such as: “integration”, “inclusive”, “diversity”, “stability” and “cohesion”. In particular, I will look at the contexts in which these words are used, their connotations, and frequency of their use. Focusing on these particular words and their meanings, I draw from the previous discourse analysis study dome by Peter S. Li (2000).

\section{Research Findings}

As my major source, I chose official reports of the Multiculturalism division of the Canadian Heritage Department. Those are policy summaries of the annual (1997/1998 to 2003/2004) Operation of the Canadian Multiculturalism Act, available on the web ${ }^{4}$. There were several reasons for focusing on these particular documents only: first, consistency in the provider of the discourse, second, possibility to track changes in the

\footnotetext{
${ }^{4}$ Can be found at http://www.pch.gc.ca/progs/multi/reports/index e.cfm
} 
Review of European and Russian Affairs vol. 2 issue 3/2006 @ RERA 2006 all rights reserved

discourse over time, and most importantly, the substance of the reports reflecting the official understanding of the values and goals of multiculturalism together with the means of their implementation. I chose to avoid other texts that discuss multiculturalism in Canada, especially media sources because of the distortions in their discourse by its internal information cycles and business interests (Chomsky, 1994, 2002, Patterson, 1998).

Structurally, every report consists of an introduction or a foreword by a prominent politician (Prime Minister, Head of the Commission on Multiculturalism, Minister or Secretary of the relevant to multiculturalism department within the government) and an overview or summary of the best practices, reforms, achievements together with highlighting the problems and challenges. The first part is the most representative and a concentrated data for the discourse analysis of the values and interests of the state in the policy of multiculturalism. The parts of the reports that summarize the successes and failures of implementing the policy of multiculturalism are larger in size and more informative but less valuable for the discourse analysis. However, they convey an important message that the government focuses more on the institutional side of the Multiculturalism Act rather than on symbolic one even though identity is primarily a symbolic phenomenon (Smith, 1991, Taylor, 1996).

I have analyzed the reports for the years of 1997/1998, 1999/2000, 2001/2002, and 2003/2004. As for the discourse changes over time, there were no significant and no irreversible shifts even after the paramount event of 9/11 attack that supposedly could have diminished the appreciation of multiculturalism. I find two possible reasons for such discourse consistency: first, no change in government ideology as liberal party was in 
power since 1993 up to 2005 and secondly, that the liberals campaigned against conservatives and the Reform party, in particular, appealing to diversity and multiculturalism as fundamental values and core of Canadian identity (Lupul, 2005).

However, the consistency of the government ideology cannot be the only reason for a no drawback to occur. Relying on my findings, and with support from the previous studies (Elliott, 1992, Abu-Laban, 1994, Li, 2003, Abu-Laban and Gabriel, 2002, Lupul, 2005), I argue that the major reason for the $9 / 11$ to not interrupt the consistently appreciative discourse on multiculturalism is the active government construction of Canadian national identity around the idea of diverse and inclusive Canada. As the Multiculturalism Act was passed in 1971 and enacted only in 1988, it is highly unlikely that multiculturalism could have been firmly enrooted as a core of the Canadian national identity. Two decades of enactment is not a sufficient period of time for any value to become engraved in any collective identity, least to say the identity of a large and heterogeneous group such as a Canadian nation. Even though diversity has been a century-long reality for Canada, by itself it cannot be a sound justification for such frequent official statements as: "multiculturalism is even more than a policy. It is a way of life. It is a value at the heart of our collective identity, “...diverse and multicultural is who Canadians are" or "multiculturalism is a core of the Canadian national identity"5 If it were indeed so, racism and discrimination based on religion and ethnicity would not be

\footnotetext{
${ }^{5}$ It is important to note though that there is evidence of a stronger connection between multiculturalism and Canadians' sense of identity. When Canadians were asked in 1999 about what contributes to their sense of identity and makes them different from Americans, multiculturalism came in second after the health care system. (2000/2001 Annual Report on the Operation of the Canadian Multiculturalism Act). However, I strongly argue that it is only indicative of the general public in Canada accepting the official discourse of constructing the national identity based on multiculturalism because racism and discrimination are still persistent in the Canadian society which directly contradicts with multiculturalism as an essential part of the Canadian national identity.
} 
Review of European and Russian Affairs vol. 2 issue 3/2006 @ RERA 2006 all rights reserved

still discussed as one of the major challenges for the successful functioning of the Multiculturalism Act in all the reports that I have examined. It is a paradox that even the latest report (2003/2004) acknowledges the fact that racism still is a part of the Canadian society which presumably practices and appreciates diversity and multiculturalism. As recent as 2004 there was a conference titled Hate and Racism in Canada: Seeking Solutions held by the Indigenous Bar Association and the National Anti-Racism Council of Canada still has a work to do in fighting racism and racial discrimination. The question arises about the commensurability of such statements as "diversity is a Canadian value" and a still pertinent need to fight racism.

Also it is been not so long ago (1960s, beginning of the 1970s) that the Canadian government pursued an assimilatory policy towards immigrants whose children were forced to live in the residential schools in order to become "more Canadian" linguistically, religiously and culturally. One of the advocates of the Multiculturalism Act in the 1970s, a Ukrainian-Canadian, Manoly Lupul shockingly compared the Canadian policies towards immigrants with the soviet policies of Russification of all the nationalities within the USSR. (Lupul, 2005: 67-102) Whereas it is possible for the government to repeatedly invoke the idea of multiculturalism being a national value and an identity for the Canadians, the change in the policy direction is not able to be reproduced so quickly in the self-perception of the society. Therefore, having analyzed the official discourse on multiculturalism I found that the first overarching theme of the reports is government persistent reinforcement of multiculturalism as a national identity component in the consciousness of the Canadians. 
I found that the official multiculturalism discourse concentrates less on positive activities and even words such as "celebrating”, “promotion”, "understanding”, “contribution” and more often emphasizes successes of the anti-racism endeavors that use negatively changed words "elimination” or “combating” of racism, "victimization” or "under-representation" of the minorities. The exception to this negative discourse is found in the Introduction to the report of 1999/2000 by the honorable Hedy Fry says:

We know that legislation alone isn't enough particularly when, as with the Canadian Multiculturalism Act, the aim is to encourage and promote change rather than taking a regulatory or coercive approach. (emphasis added).

Another macro observation is that with the exception of the 1999/2000 report the major discourse employed in discussing multiculturalism is institutional or functional. By this I mean that the reports are concerned with "making federal and provincial institutions more reflective of the diverse Canadian society" (2003/2004), "diversity lens should be implemented in how government agencies deliver their policies", "being proud of the activities undertaken by federal departments and agencies to support multiculturalism and build a stronger, more united Canada” (2001/2002). The majority of the discussion in the reports is devoted to public spending, of how various state institutions implement the Multiculturalism Act, and cooperate with ethnic communities. For instance, in the 2003/2004 report:

The increasing diversity of the Canadian population requires government institutions to examine their policies, programs and services to ensure that they are accessible to all Canadians and meet the changing needs of a multicultural population. ...role of the public servants in promoting the values of diversity and respect in their programs, policies and service delivery. (emphasis added). 
The first question to ask is who defines the needs of various ethnic groups, second, what if their identity does not require any special service but merely recognition and lastly, I can hardly picture a bureaucrat widely promoting values of diversity in his delivery of the public services. Issues of diversity, identity and symbolic pluralism are more influentially promoted by the public figures such as intellectuals or top politicians whose discourse is known for a wider public than just the particular groups or individuals who receive the particular services. It is not that I argue about diminishing the importance of the institutional aspect of the multiculturalism policy or the significance of the government funding for the successful maintenance of diversity, however, I am concerned with the symbolic discourse nearly absent in these official documents. The only report where I found such words as "belonging”, "sense of pride”, "partnership”, and such phrase as

There are many different views about which outcomes matter most. Measures themselves influence the way policies are implemented and programming is designed and delivered. For example, is it more important to help 100 people get started on a journey or to help 10 people who are most in need to complete it? Certainly, it matters that we reach as many people as possible. But the effectiveness of what we do in reaching them matters more. In the case of multiculturalism, this means attitudes and expectations and a sense of pride and belonging. These are difficult outcomes to measure and even harder to attribute to one government initiative or program. (emphasis added).

This is from an Introduction by the Honorable Hedy Fry, Secretary of State on Multiculturalism and Status of Women, for the report of the year 1999/2000. I can contribute this only case of rhetoric which at least minimally employed symbolic attributes of identity issue to the fact that it was written by a woman. This idea is also supported with her overall use of narrative rather than explanatory or informative style in her Introduction, which is considered a distinction of a feminine expression. 
Review of European and Russian Affairs vol. 2 issue 3/2006 @ RERA 2006 all rights reserved

The next major theme to discuss is a concern of the Canadian government about social cohesion. In the majority of times discussion of diversity and "various racial, ethnic, and religious groups” goes together with the issue of social cohesion. Whenever social cohesion or stability is mentioned, the word "inclusive" or "inclusion" appears as well. There are NO cases that I noted where "diversity" would be mentioned just by itself as a sign of celebrating its very presence. It is always used in the context of "integrating" or "inclusive" government actions "to build a cohesive and diverse Canadian society". Conversely, "not recognizing diversity is dangerous and neglects opportunities for prosperous and just Canada”. Deconstructing this discourse, it appears that diversity by itself is not celebrated within the policy of multiculturalism rather it is acknowledged as an inevitable fact and is being dealt with through "inclusion" and "integration" of the various cultural groups with the major goal of maintaining stability and cohesiveness of the Canadian nation.

As I already mentioned, the word "partnership” was used just once, other than that it is always "Canadian society" which "includes ethnic, racial, cultural minorities". The question arises naturally about how it corresponds with "multiculturalism being a value at the heart of our [Canadian] collective identity" if the diversity should be incorporated into the mainstream Canadian culture. Obviously, the policy of "inclusiveness" is meant to combat the social injustices and racism but the discourse reveals that the government is interested in multiculturalism as long as it does not contradict with social cohesion and internal stability of a country. In a large society to maintain those it is inevitable to acknowledge diversity and to give it a limited freedom with the condition of this diversity being integrated over time into conventional culture. How much then this kind of 
Review of European and Russian Affairs vol. 2 issue 3/2006 @ RERA 2006 all rights reserved

"inclusiveness" allows for maintaining "diversity"? If Canadian society aims at including all the diverse ethnic groups, how is it possible for the latter to maintain their distinctive differences?

Going back to the Canadian state preoccupation with the "social cohesiveness", the most vivid and representative example of this discourse is the phrase from 2001/2002 report:

The explicit recognition that diversity within a common citizenship is good, which is what multiculturalism is all about, encourages Canadians to feel committed to Canada, fostering a sense of belonging and attachment to the country and to one another, a collective state of being otherwise known as "social cohesion." As Canada becomes increasingly diverse, efforts to strengthen social cohesion between and among all the many ethnic, racial and religious groups in Canadian society will be central to our continued progress as a modern, united and democratic society. (emphasis added).

In every report that I have examined the most frequent use of the word "equality" was in the meaning of economic, social and political equality of the "various minorities" and "Canadian society". I have traced none phrases mentioning "equality" with cultural or symbolic connotation. No doubt, the political and socioeconomic aspects of equality are vital for an individual success in a modern society such as Canada; however, this type of equality implies that all ethnic groups aspire to perform in the Canadian economy and politics. Moreover, socioeconomic and political equality undermines the fact that some ethnic groups strive just for the recognition of their difference which requires only cultural and symbolic equality without any social endowments. If the main value of multiculturalism is "celebrating diversity", then initially equality should be recognized in cultural terms, meaning that values and life attitudes of various ethnic groups are equal in their difference rather than different from the mainstream. The phrase representative of 
this idea is from the foreword by Jean Chretien, a Prime Minister back then, in the 1997/1998 report:

All Canadians regardless of their background will continue to work together ensuring participation of all citizens in all the aspects of society. (emphasis added).

I suggest that if multiculturalism is meant to celebrate diversity, the phrase "regardless of their background" quite undermines this endeavor.

Another prevailing theme of the official multiculturalism discourse is "participation" or "active citizenship". The government aims at "ensuring Canadians of diverse backgrounds to fully participate in the political, economic and cultural life of our country." The value of taking part in the social institutions is clearly emphasized for being a "true Canadian citizen". This is again the intertwined discourse of "inclusion" "integration” and "cohesion” that does not allow for diversity and ethnic differences per se to be the main focus of multicultural citizenship. Diversity is allowed for the ethnic groups to the extent of their adherence to the image of Canada as it existed before this particular group appeared on its territory. "Participation in all aspects of Canadian life" means that immigrants or individuals of the ethnic backgrounds that are very different from what Canada was before the official announcement of multiculturalism should accept the already existing institutions and to participate in those despite possible incommensurability with their ethnic values.

Next, it almost seems that the official discourse on multiculturalism bears resemblance to political correctness in such goals as: "inclusion of visible minority actors cast in leading and recurring roles; and initiatives implemented to ensure that scripts not portray minorities in a stereotypical manner" or that "visible minorities should 
be represented in all levels of government agencies”. However, I argue for the converse acknowledgement that multiculturalism is much more that political correctness if it aspires to reach its goals of "cross-cultural understanding."

The final point that stands out from the official discourse on multiculturalism is the underlying assumption that there is a "modern", "normal" and "civilized" (not quoted from the reports) Canadian general culture that is juxtaposed to "visible minorities", "ethnic, religious, cultural, racial minorities". Here is a couple of the most representative phrases of this discourse: "women torn between western and Muslim traditions.” (1997/1998 report) and from the latest (2003/2004) report:

Multiculturalism is a policy of inclusion that aims to help people overcome barriers related to race, ethnicity and cultural or religious background. And: (emphasis added).

Multiculturalism is a social model that is an example for the world and is founded on the belief that diversity is synonymous with success, prosperity and the future. (emphasis added).

This kind of treating ethnic values as barriers means not respecting them as differences worthy of cherishing and, moreover, rejecting the fact that some cultures define diversity in the opposite way, namely, without reference to success and prosperity as for some cultures those are not values at all. Also this discourse is premised on the assumption that members of ethnic communities have it as a goal to become a part of the "wider” Canadian society and therefore, they should forsake their adherence to ethnic values which endanger mainstream Canadian culture. Such premises cannot be a part of the kind of multiculturalism which embraces and promotes ethnic and cultural diversity. Finally, even the very use of the term "visible minorities" undermines the idea of diversity and multiculturalism in at least two ways: it implies existence of non-visible 
majority and it undermines differences within both visible minorities and non-visible majority.

Overall, the idea of "integration" is expressed in the official discourse on multiculturalism as a result of immigrants or members of ethnicities to conform to the "Canadian values”, which are claimed to be "tolerance, equality, justice and diversity" (2003/2004 report). “Integration” occurs not as a result of a deeper cross-cultural partnership and understanding but rather through the "inclusion” or "active participation" of the members of various diverse groups into a standard North American culture. This idea is reinforced in the discourse which juxtaposes "Canadian society" to "ethnic, racial, cultural, religious minorities" that reoccurs as a major theme in all the reports on the operation of the Multiculturalism Act in Canada.

\section{Significance of the Research Findings and Conclusions}

Overall, my research question was supported with the discourse analysis data, specifically; it appears that the policy of multiculturalism in Canada might serve the persistent goal of the state to homogenize its population in order to ensure internal stability. The official discourse of the Canadian policy of multiculturalism seems to reveal that the underpinning motivation of this policy is not simply to integrate immigrants or to facilitate an understanding between various ethnic groups but rather is to conform the immigrants and ethncities into the mainstream Canadian way of socioeconomic, political life and, most important, of attitudes and values with only superficial cultural expressions of ethnic identities (food, festivities, garments). 
The research findings support the idea by Roger Brubaker about how cultural idioms shape citizenship regimes with an example of a new country. In the case of Canadian multiculturalism there was initially a distinct feature of Canada that makes it different from other cases of immigrant nations and allowed for an easier transition to a multicultural citizenship. It is "an extraordinarily disperse pattern of geographic settlement”, as Cole Harris (2001: 194) put it, that allowed for ethnic groups to maintain their patterns of economic and cultural reproduction for a longer time than in other immigrant nations. The Prairies in Canada, unlike any land in the US or Australia, were from the beginning of settlement inhabited mainly by the German-Scandinavian or the Polish and the Ukrainian communities. This "postmodern patriotism” (Ibid. 193, 197) is what makes Canada a unique nation, what allows for a political institutional solidarity with ethnic and cultural diversity as contrary to the "melting pot". Therefore, policy of multiculturalism in Canada did not emerge at once and is not a proof of exceptional benevolence to the immigrants since Canadian "mosaic" was not the planned positive government policy but rather a pattern of residing of the various ethnicities that allowed for them to stay for a long time not intermingled with other ethnic groups and to the mainstream Anglo-Celtic or French cultures.

The deconstruction of the multiculturalism discourse is also in line with the findings of Adrian Favell and his seminal work on the philosophies of immigrants' integration. Introducing a new case to his comparative framework, first supports his argument about ethnic dilemmas of the liberal democratic states and also contributes to a deeper understanding of how state policies towards immigrants are shaped within broader philosophies of nations. The case of Canada appears to support Favell’s idea. 
The research findings support also the historical institutionalism study by Jane Jenson (1997) about the changing nature of the Canadian citizenship regime due to the transformations in the dynamics of internal political institutions and neo-liberal international trade regimes. Thus, change in government ideologies from the "quiet revolution" and Trudeau in 1960s then to the neoconservatives in the 1980s and finally to the reform liberals in 1993 contributed to the changes in the understanding of the Canadian citizenship with the consequent reforms such as policy of multiculturalism coupled with the instabilities and changes in the social welfare. Also, the findings provide an episodic support for the importance of "participatory" or "active" citizenship in the republican understanding of nation (Sicakkan, 2004). In this, Canada appears similar to the US and France in their concern with the civic political culture of its citizens.

The research findings are also significant for the studies on multicultural citizenship. It is a good empirical observation for the political theorists who advocate this kind of citizenship such as Isis M Young, Will Kymlicka and Charles Taylor. My thinking suggest that it is rather a disproof than support for their arguments about benevolence of multiculturalism as it appears to be less liberal than they suggest. The deconstruction of the official Canadian discourse on multiculturalism suggests that it can be simply a more sophisticated and a better veiled strategy of assimilating immigrants than the US “melting pot” or the republican France. In this my findings support another study by Reitz and Breton (1994) which showed that Canada and the US incorporate ethnic groups into host society similarly, despite the popular belief that Canadian "mosaic" allows for preserving one’s ethnicity. Essentially, North American culture assimilates ethnic and cultural minorities into its way of life. 
Overall, it is questionable if the policy of multiculturalism as practiced in Canada should be a model for the European nations in order to reduce the social cleavages persistent in the host societies with regards to immigrants and ethnic minorities. First of all, multiculturalism appears to be quite specific for Canada, or to use terms of Brubaker and Favell, a Canadian cultural idiom and philosophy of immigrants' integration. Therefore, it is not easily transferable into other nations with established cultural idioms of their own. Most importantly, the Canadian government in its policy of multiculturalism is not selflessly liberal and pursues the same goal of homogenizing its population as the "old” European nations. In this respect, my findings fundamentally contradict the popular proposals of employing Canadian multiculturalism for the European nations (Castles et al. 1994, Carnes et al., 1994, Inglis, 2003), which were the start point for my inquiry.

The majority of the studies on multiculturalism policy in Canada follow the frameworks of the economics of migration, institutional, public administration, or public policy studies, with discourse analysis being utilized only in the mentioned before Peter S. Li's book and episodically in the book by Y. Abu-Laban and C. Gabriel. However, as this research provided a number of significant insights, it is a good contribution to the studies on the Canadian policy of multiculturalism. It is important also that some of the conclusions drawn from deconstructing the official discourse on multiculturalism support some of the major ideas discussed within other frameworks. For instance, my findings 
hold true for the argument of Canada "selling diversity" expressed in the book under the same name by Y. Abu-Laban and C. Gabriel. ${ }^{6}$

As the discourse deconstruction showed, there is a misbalance in structural versus symbolic language in the policy of multiculturalism represented in such statements as "Institutional change is a fundamental step in eliminating systemic inequality." (2003/2004 report) In this my findings support Elliott's argument that the success of the policy of multiculturalism should come from "restructuring of the symbolic order to incorporate all identities on an equal basis” (1992: 73), or what Brotz and Roberts and Clifton describe as “token or symbolic pluralism” (Li, 2003: 135).

The research appeared to be quite dispersed in its focus and touched on many issues connected to the state sovereignty with respect to the state pursuit of internal stability through homogenizing its population. This lack of clear focus is the main weakness of my study. However, it would be impossible to report the findings and their significance without all the extensive background information provided. Overall, the discourse analysis of the official documents on the policy of multiculturalism in Canada substantiated my assumptions about continuous state pursuit of homogenizing its inhabitants. As the contemporary stage of state development is marked with liberal democratic discourse, Canada seems to have chosen a very sophisticated way of

\footnotetext{
6 The discourse that represents this idea is: "Canada can capitalize on its diversity." (2003/2004 report). Also, as Prime Minister Jean Chrétien noted in 1998: "Canadians have learned that their two international languages and their diversity are a comparative advantage and a source of continuing creativity and innovation." Or, as recent (2001) public opinion polling shows that more than two-thirds of Canadians believe that Canada's culturally diverse population is a competitive advantage in the global economy. (from the 2001/2002 report).
} 
assimilating immigrants and ethnicities in general. On a surface its multiculturalism policy appears very benevolent to the individuals from diverse ethnic backgrounds but deconstruction of the official discourse revealed the presence of the veiled interest of the Canadian state to preserve its internal stability. As ethnic values of the immigrants can endanger the conventional Canadian political culture, policy of multiculturalism still requires diversity to conform to the mainstream. There is a necessity of a standard Canadian who can be diverse culturally or ethnically but who is still a Canadian. Multiculturalism requires a balancing on the edge of ethnic separatism or claims of being one of the constitutive nation groups. Multiculturalism as a philosophical ideal is liberally and democratically benevolent and ambitious but claims far more than it can achieve without endangering sovereignty and oneness of Canada. In turn, the real policy of multiculturalism is far more pragmatic and stems from the state necessity of maintaining internal cohesiveness, which is easier to achieve if the population is homogeneous. 


\section{Bibliography}

Castoriadis, Cornelius. 1997. The Imaginary Institution of Society. (3 ${ }^{\text {rd }}$ ed.). Cambridge: Polity Press.

Castles, Stephen. 1994. "Democracy and Multicultural Citizenship. Australian Debates and their Relevance for Western Europe." In Baubock, Rainer (ed.). From Aliens to Citizens. Redefining the Status of Immigrants in Europe. European Centre Vienna. pp. 329.

Martiniello, Marco. 1994. "Citizenship of the European Union. A Critical View.” In Baubock, Rainer (ed.). From Aliens to Citizens. Redefining the Status of Immigrants in Europe. European Centre Vienna. pp. 29-49.

Carens, Joseph H. “Cultural Adaptation and Integration. Is Quebec a Model for Europe?” In Baubock, Rainer (ed.). 1994. From Aliens to Citizens. Redefining the Status of Immigrants in Europe. European Centre Vienna. pp.149-187.

Jenson, Jane. 1997. “Fated to Live in Interesting Times: Canada’s Changing Citizenship Regimes.” Canadian Journal of Political Science. Vol. XXX:4. pp.627-645.

Harles, John C. 1997. "Integration before Assimilation: Immigration, Multiculturalism and the Canadian Polity." Canadian Journal of Political Science. Vol. XXX:4. pp. 711737.

Green, Joyce A. 2000. “The Difference Debate: Reducing Rights to Cultural Flavors.” Canadian Journal of Political Science. Vol. XXXIII:1. p.133-45.

Abu-Laban, Yasmeen and Gabriel, Christina. 2002. Selling Diversity. Broadview Press.

Abu-Laban, Yasmeen and Nieguth, Tim. 2000. "Reconsidering the Constitution, Minorities and Politics in Canada." Canadian Journal of Political Science. Vol. XXXIII:3. pp. 465-499.

Abu-Laban, Yasmeen. 1994. "The Politics of Race and Ethnicity: Multiculturalism as a Contested Area.” In: J. Bickerton \& A.-G. Gagnon (eds.). Canadian Politics (2 ${ }^{\text {nd }}$ ed.). Ontario Broadview Press. pp. 242-267.

Elliott, Jean L. and Fleras, Augie. 1992. Unequal Relations. An Introduction to Race and Ethnic Dynamics in Canada. Scarborough, Ontario: Prentice-Hall Canada Inc.

Faist, Thomas. 2004. "Dual Citizenship as Overlapping Membership.” In: Daniele Joly (ed.). International Migration in the New Millenium. Aldershot, England: Ashgate Publishing Comp.

Joly, Daniele. 2004. “Between Exile and Ethnicity.” In: Daniele Joly (ed.). International Migration in the New Millenium. Aldershot, England: Ashgate Publishing Company.

Lupul, Manoly R. 2005. The Politics of Multiculturalism. A Ukrainian-Canadian Memoir. Edmonton - Toronto: Canadian Institute of Ukrainian Studies Press. 
Lecours, Andre. 2000. "Theorizing Cultural Identities: Historical Institutionalism as a Challenge to the Culturalists.” Canadian Journal of Political Science. Vol. XXXIII:3. pp. 499-523.

Fierlbeck, Katherine. 1996. "The Ambivalent Potential of Cultural Identity.” Canadian Journal of Political Science. Vol. XXIX:1. p.3-23.

Brubaker, Rogers. 1992. Citizenship and Nationhood in France and Germany. Cambridge, MA: Harvard University Press.

Favell, Adrian. 2001. Philosophies of Integration: Immigration and the Idea of Citizenship in France and Britain. ( $2^{\text {nd }}$ ed.) Houndmills, Basingstoke: Macmillan Press.

Inglis, Christine. 2003. Multiculturalism: New Policy Responses to Diversity. Policy Paper no. 4 for the UNESCO Project "Management of Social Transformations".

Subramanian, Narendra. 1996. "Ethnicity and Pluralism: An Exploration with reference to Indian Cases.” Canadian Journal of Political Science. Vol. XXXII:4. pp.715-745.

Smith, Anthony D. 1991. National identity, Reno: University of Nevada Press.

Harris, Cole. 2001. "Postmodern Patriotism: Canadian Reflection." Canadian Geographer. 45(1). pp. 193-207.

Schulze, Hagen. 1994. States, Nations, and Nationalism. Cambridge, MA: Blackwell.

Scott, James C. 1998. Seeing Like a State: How Certain Schemes to Improve the Human Condition Have Failed. New Haven, CT: Yale University Press.

Mann, Michael. 1984. "The Autonomous Power of the State: Its Origins, Mechanisms, and results.” European Journal of Sociology 25(2): pp. 185-213.

Tilly, Charles. 1990. Coercion, Capital and European States, AD 990-1990. Cambridge, MA: Basil Blackwell.

Riesenberg, Peter. 1992. Citizenship in the Western Tradition: Plato to Rousseau. The University of North Carolina Press.

Guiraudon, Virginie. 1998. "Citizenship Rights for Non-Citizens: France, Germany, and the Netherlands.” In: Christian Joppke (ed.). Challenge to the Nation-State: Immigration in Western Europe and the United States. New York: Oxford University Press. pp. 273318.

Soysal, Yasemin Nuhoglu. 1998. "Toward a Postnational Model of Membership.” In Gershon Shafir (ed.). The Citizenship Debates: A Reader. Minneapolis: U-ty of Minneapolis Press. pp. 189-217.

Torpey, John. 1998. "Coming and Going: On the State Monopolization of the Legitimate "Means of Movement”, Sociological Theory, Vol. 16, No. 3. pp. 239-259. 
Engbersen, Godfried. 2001. "The Unanticipated consequences of panopticon Europe: Residence Strategies of illegal immigrants.” In Virginie Guiraudon and Christian Joppke (eds.). Controlling a New Migration World. New York: Routledge. pp. 222-246.

Sikaccan, Hakan G. 2004. Envisioning Togetherness. Edwin Mellen Press.

Lahav, Gallya and Virginie Guiraudon. 2000. "Comparative Perspectives on Border Control: Away from the Border and Outside the State.” In Peter Andreas and Timothy Snyder. The Wall Around the West: State Borders and Immigration Controls in North America and Europe. New York: Rowman \& Littlefield. pp.55-77.

Money, Jeanette. 1997. "No Vacancy: The Political Geography of Immigration Control in Advanced Industrial Countries.” International Organization 51(4). pp. 685-720.

Ellermann, Antje. 2005. "Coercive Capacity and the Politics of Implementation: Deportation in Germany and the United States." Comparative Political Studies 38(10). pp.1219-1244.

Freeman, Garry. 1995. "Modes of Immigration Politics in Liberal Democratic States." International Migration Review. No. 4. pp. 881-902.

Joppke, Christian. 1998. "Why Liberal States Accept Unwanted Immigration.” World Politics 50. pp. 266-293.

Sassen, Saskia. 1998. “The de facto Transnationalizing of Immigration Policy.” In: Christian Joppke (ed.). Challenge to the Nation-State: Immigration in Western Europe and the United States. New York: Oxford U-ty Press. pp. 49-85.

Guiraudon, Virginie. 2000. "European Integration and Migration Policy: Vertical Policymaking as Venue Shopping.” Journal of Common Market Studies 38(2). pp.251-271.

Jenson, Jane. 1994. "Understanding Politics: Contested Concepts of Identity in Political Science.” In: J. Bickerton \& A.-G. Gagnon (eds.). Canadian Politics ( $2^{\text {nd }}$ ed.). Ontario Broadview Press. pp.54-75. 